\title{
Erzurum İlinde Yetiștirilen Bazı Bakla (Vicia faba L.) Çeșit ve Popülasyonlarının Verim ve Bazı Agromorfolojik Özellikleri
}

\author{
Sibel KADIOĞLU@ \\ Doğu Anadolu Tarımsal Araștırma Enstitüsü, Erzurum, Türkiye \\ Sorumlu yazar e-posta (Corresponding author e-mail): sibel.kadioglu@hotmail.com \\ Geliș Tarihi (Received): 25.10.2019 Kabul Tarihi (Accepted): 20.12.2019
}

\begin{abstract}
Öz
Farklı illerden toplanılan 15 bakla popülasyonu ve 6 tescilli bakla çeșidi (Lara, Seher, Filiz-99, Eresen-87, Kıtık ve Salkım) kullanılarak Doğu Anadolu Tarımsal Araștırma Enstitüsü Pasinler deneme alanında tesadüf blokları deneme desenine göre üç tekerrürlü olarak yürütülen çalısmada baklanın yemlik olarak Erzurum ekolojisine uyumu ve verim unsurları açısından değerlendirilmesi amaçlanmıștır. Araștırmada 21 farklı bakla çeșit ve popülasyonun yem olarak kullanımında etkili olan bazı özelliklerinde iki yılın ortalama değerleri; dal sayısı 4.1 adet, ilk bakla yüksekliği $26.4 \mathrm{~cm}$, bitki boyu $59.3 \mathrm{~cm}$, bitki bașına bakla sayısı 14.9 adet, baklada tane sayısı 3.2 adet, çiçeklenme bașlangıcı gün sayısı 56 gün, fizyolojik olum gün sayısı 119.4 gün ve tohum verimi $165.6 \mathrm{~kg}$ da-1 olarak belirlenmiștir. En yüksek tohum verimi ilk yıl Eresen-87 çeșidinde ikinci yıl ise Tokat popülasyonundan alınmıștır. İki yıllık birleștirilmiș deneme sonuçlarının varyans analizinde çeșit/popülasyon ve yıllar arasında önemli farklııklar olduğu ortaya çıkmıș, korelasyon analizinde ise tohum verimi ile çiçeklenme bașlangıcı ve fizyolojik olum gün sayısı arasında negatif ama önemli bitki boyu ve bitkide tane sayısı arasında ise olumlu ve istatistiksel olarak anlamlı bir ilișki olduğu belirlenmiștir. Çoğu ıslah çalıșmasında olduğu gibi bu kriterlerin aynı ekolojide yapılacak olan ıslah çalıșmalarında seleksiyon kriteri olarak kullanılabileceği düșünülmektedir.
\end{abstract}

Anahtar Kelimeler: Erzurum, ekoloji, bakla, tohum verimi, bakla yetiștiriciliği

\section{Seed Yield and Certain Agromorphological Characteristics of Some Broad Bean (Vicia faba L.) Varieties/Populations Grown in Erzurum Province}

\section{Abstract}

Fifteen broad bean populations collected from different provinces and six commercial broad bean varieties (Lara, Seher, Filiz-99, Eresen-87, Kitık and Salkım) as a standard were used as plant material in the study. The experiments was carried out at Eastern Anatolia Agricultural Research Institute Pasinler trial area according to complete randomized block design with three replications. The aim of the study is to determine yield elements of broad bean as feedstuff in Erzurum ecology. In the study, the mean values of some agronomic characteristics of 21 different broad bean variety/ populations used as feed for two years were determined as in number of branches 4.1 , first pod height $26.4 \mathrm{~cm}$, plant height $59.3 \mathrm{~cm}$, number of pods per plant 14.9 , number of beans per pod 3.2, number of days to beginning of flowering 56 , number of days to seed physiological ripening 119.4 days and seed yield $165.7 \mathrm{~kg}$ da-1. The highest seed yield was obtained from CV Eresen-87 in the first year and from the population of Tokat in the second year. A combined analysis of variance was performed for the two-year research results and significant differences were found between genotypes and years. In the correlation analysis, it was suggested that there was a negative but significant relationship between seed yield and number of flowering days and the number of days to physiological maturity. Also, there was a positive but very significant relationship between seed yield and plant height and number of seeds per pods. It is thought that these parameters could be used as selection criteria in breeding studies conducted in the similar ecological conditions.

Keywords: Erzurum, ecology, faba bean, seed yield, culture of broad bean 


\section{Giriș}

Bakla yetiștiriciliği yapılan en eski ve en yaygın kültür bitkisidir. Gen merkezinin Güneybatı Asya ve Akdeniz olduğu bildirilmekle beraber genellikle küçük daneli baklalar İran, Türkmenistan, Afganistan ve Kuzey Hindistan'da toplanmıștır (Şehirali, 1988). Atbaklası, eșek baklası veya hayvan baklası olarak da adlandirlan baklalar yem olarak değerlendirilir ve üretim alanı çok azdır. Makineli tarıma geçilmeden önce özellikle gücünden yararlanılan hayvanların beslenmesinde önemli bir yer tutan hayvan baklası ülkemizde en fazla Batı Marmara Bölgesi'nde yetiștirilmektedir. Çalıșma alanının yer aldığı Doğu Anadolu Bölgesi'nde ise az da olsa bazı illerde geleneksel olarak yetiștirilmektedir.

Ülke genelinde yıllara bağlı olarak bakla ekilișlerinde artıș görülmekle birlikte 2013 yilında belirli bir oranda azalıs olmuștur (18 bin da), özellikle bu düșüș Akdeniz Bölgesi'nde oldukça fazla olmuș ve Türkiye geneline yansımıştır. Bu düșüșle birlikte 2018 yılında kuru bakla (yemlik) 22.428 da alana ekilmiș ve 7 bin ton üretim olmuștur (TÜiK, 2019). Kültürü yapılan bakla çeşitleri sistematik açıdan üç grupta toplanır, bu gruplar arasında morfolojik ve tohum özellikleri açısından önemli farklııklar vardır. Özellikle tanesi küçük olan baklalar hayvan beslenmesinde kullanılır. Diğer baklagiller gibi hayvan baklası iyi bir münavebe bitkisidir. Silaj olarak değerlendirildiği gibi hasat sonrası elde edilen samanı da değerlidir. Kuru ot verimi yaklașık dekara $350 \mathrm{~kg}$ olan baklanın ham protein oranı \% 25 oranında olabilir (Geren ve Alan, 2005). Kuru bakla daneleri yaklașık \%20-36 oranında protein içeriği ile insan ve hayvan beslenmesinde büyük öneme sahiptir (Şehirali, 1988; Açıkgöz, 2001). Çalışma alanında geçim özellikle hayvanclık ile sağlanmaktadır. Kış döneminde hayvanların yeterince beslenebilmesi ve özellikle meraların korunması amacıyla alternatif yem bitkilerinin yetiștirilmesi zorunlu hale gelmiștir. Bu çalıșmada değișen iklim koșulları ile ürün deseninin de değișebileceği göz önüne alınarak baklanın hayvan beslenmesinde alternatif ürün olabilirliği, Erzurum ekolojisine adaptasyonu ve bazı tarımsal özellikleri incelenmiștir.

\section{Materyal ve Yöntem}

Araștırma, Doğu Anadolu Tarımsal Araștırma Enstitüsü'nün Pasinler deneme alanında 2 yıl (2012-2013) süreyle yürütülmüștür. Bitkisel materyal olarak denemede, Çizelge 1 'de verildiği gibi kullanım amacı yem olan ve ülkenin farklı yörelerinden toplanmıș popülasyonlar ile yaygın olarak kullanılan bazı tescilli çeșitler kullanılmıștır. Temin edilen bakla tohumları 2011 yılında üretilen yemlik bakla üreticilerinden alınmıştır. Her üretici ayrı bir örnekleme olarak kabul edilmiș ve materyal kullanımı kodları ile alındıkları yerler Çizelge 1 'de verilmiștir. Deneme tesadüf blokları deneme desenine göre üç tekerrürlü olarak 2012-2013 yılı ilkbaharında Nisan ayı sonunda kurulmuștur. Ekimler $5 \mathrm{~m}$ uzunluğunda ki parsellere, metrekarede 15 bitki hesabıyla

Çizelge 1. Denemede kullanılan bitkisel materyal ve temin edilen yerler

Table 1. Plant material used in the experiment and places provided

\begin{tabular}{llcl}
\hline Genotip & Temin edildiği yer & Genotip & Temin edildiği yer \\
\hline a1 & Adapazarı/Geyve & $\mathrm{m} 1$ & Trabzon/Maçka \\
a2 & Adapazarı/Merkez & $\mathrm{m} 2$ & Muğla/Merkez \\
a3 & Adapazarı/Merkez & $\mathrm{s} 1$ & Samsun/Merkez \\
a4 & Adapazarı/Kahramanlar & $\mathrm{t} 1$ & Tokat/Merkez \\
a5 & Adapazarı/Erenler & $\mathrm{e} 1$ & Filiz -99 (Ege Tarımsal Araștırma Enstitüsü) \\
an1 & Antalya/Manavgat & e2 & Eresen-87 (Ege Tarımsal Araștırma Enstitüsü \\
an2 & Antalya/Topallı & e3 & Kıtık (Ege Tarımsal Araștırma Enstitüsü) \\
b1 & Balıkesir/Gönen/Gündoğan & e4 & Salkım (Ege Tarımsal Araștırma Enstitüsü) \\
b2 & Balıkesir/Gönen/Sarıköy & $\mathrm{L}$ & Lara (May Tohumculuk) \\
ç1 & Çanakkale/Bayramiç/Örende & $\mathrm{S}$ & Seher (May Tohumculuk) \\
\hline ç2 & Çanakkale/Dağahmetçe & & \\
\hline
\end{tabular}


Çizelge 2. Deneme alanlarının toprak analiz sonuçları

Table 2. Soil analysis results of the trial areas

\begin{tabular}{lcccccc}
\hline Yll & $\mathrm{pH}$ & Kireç \% & Tuz \% & Organik madde \% & Fosfor kg da $^{-1}$ & Potasyum kg da $^{-1}$ \\
\hline 2012 & 7.56 & 1.96 & 0,11 & 1.38 & 5.4 & 92.0 \\
\hline 2013 & 7.54 & 6.02 & 0,13 & 3.82 & 21.9 & 339.0 \\
\hline
\end{tabular}

$70 \mathrm{~cm}$ sıra arası ile 5 sıra şeklinde yapılmıștır. Baklalar genel olarak kıșlık ekildiğinden sulamaya gerek duyulmaz ancak çalıșmada yazlık olarak ilkbaharda ekilen baklalarda yağıșlara bağlı olarak gelișmeyi özellikle tane gelișmesini olumlu etkileyeceğinden (Şehirali, 1988) çiçeklenme öncesi, bakla oluşumu ve sonrası olmak üzere $3 \mathrm{kez}$ sulama ve her sulamadan sonra çapa yapılmıştır. Her bir parselden on bitki seçilmiș ve seçilen her bitkide dal sayısı, ilk bakla yüksekliği, bitki boyu, bitkide bakla, baklada tane sayıları alınmıștır (Pekșen, 2007). Verilerin istatistiki analizi yıllar üzerinden birleștirilerek JUMP paket programında yapılmıș ve çoklu karșılaștırmalarda LSD testi kullanılmıștır. Tohum verimi ve verim unsurları arasındaki ilișkileri belirlemek amacı ile korelasyon analizi yapılmıștır (Pekșen, 2007; Karadavut ve ark., 2011). Deneme alanı Pasinler ovası içerisinde yer almaktadır. Yapılan toprak analiz sonuçlarına göre; ilk yıl ekimlerinin yapıldığı deneme alanı toprakları tınlı, hafif alkali, kireçli, tuzsuz, organik madde ve fosforu az, potasyumca zengindir. İkinci yıl ekimlerinin yapıldığı deneme alanı toprakları ise killi-tınlı, hafif alkali, orta kireçli, tuzsuz, organik maddece fakir, fosforu çok ve potasyumca oldukça zengin olarak belirlenmiștir (Çizelge 2).

Baklagiller toprak isteği bakımından ne ağır ne de fazla hafif toprakları tercih etmezler, tınll- humuslu ve kireççe zengin, $\mathrm{pH}$ 6-8 arasında, azot ve fosforca zengin toprakları isterler (Akçin, 1988; Kün ve ark., 2005). Bu kapsamda hayvan baklası da tınlı-killi, nötr veya hafif alkali, geçirgen ve organik maddece zengin topraklarda yetiștirilmelidir (Akçin, 1982). Toprak analiz sonuçlarına göre deneme alanları toprakları hayvan baklasının intiyaçları karșılayabilecek kapasitedir (Çizelge 2).

Çalışmanın yürütüldüğü yıllarda vejetasyon süresince aylık sıcaklıklar ve nispi nem değerlerinin hemen hemen birbirine yakın değerlerde olduğu görülmektedir. Yağışlar ise 2013 yll yetiştirme periyodunda (Mayıs, Haziran, Temmuz, Ağustos) 2012'ye nazaran daha az olmuştur. Yıllık yağış toplamı 2013'de daha fazla olmasına rağmen yağışların aylara dağılımında farklıık olmuş Temmuz ve Ağustos aylarında bir önceki yıla oranla daha az yağış düşmüştür (Çizelge 3).

Nem miktarının \%60-\%70 arasında yoğunlaștığı özellikle Mayıs ve Eylül aylarında yüksek olduğu görülmektedir. Buna karșın en düșük nem miktarı her iki yılda Ağustos ayında olmuştur. Yem baklasının vejetasyon süresi uzun olmasına rağmen sıcaklık isteği düșüktür. Ancak denemenin yürütüldüğü her iki yılda toprak, sıcaklık, yağıș ve nem gibi bazı çevresel faktörlerin etkisi ile verim ve verim

Çizelge 3. Araștırmanın yürütüldüğü yıllara ait ortalama sıcaklık, aylık toplam yağıș ve ortalama nispi nem değerleri

Table 3. Average temperature, monthly total rainfall and average relative humidity values of the research years

\begin{tabular}{llccccccc}
\hline \multirow{2}{*}{ YIL } & \multicolumn{7}{c}{ AYLAR } \\
\cline { 2 - 8 } & İklim Faktörleri & Nisan & Mayıs & Haziran & Temmuz & Ağustos & Eylül & $\begin{array}{c}\text { Vejetasyon } \\
\text { süreci }\end{array}$ \\
\hline \multirow{2}{*}{2012} & Ort. Sıcaklık $\left({ }^{\circ} \mathrm{C}\right)$ & 5.9 & 10.1 & 15.0 & 19.4 & 19.0 & 13.9 & 13.9 \\
& Toplam yağıș $(\mathrm{mm})$ & 16.0 & 47.5 & 29.0 & 10.0 & 15.0 & 16.0 & 133.5 \\
& Ort. nispi nem (\%) & 63.8 & 64.0 & 54.6 & 54.6 & 47.6 & 54.9 & 56.6 \\
\hline \multirow{2}{*}{2013} & Ort. Sıcaklık ( $\left.{ }^{\circ} \mathrm{C}\right)$ & 7.2 & 11.6 & 16.0 & 18.8 & 20.4 & 15.1 & 14.9 \\
& Toplam yağıș (mm) & 45.0 & 32.0 & 26.5 & 7.5 & 6.0 & 72.0 & 189 \\
& Ort. nispi nem (\%) & 58.5 & 61.4 & 58.6 & 51.9 & 47.6 & 47.8 & 54.3 \\
\hline
\end{tabular}


parametrelerinde de farklılıklar tespit edilmiștir (Çizelge 2-3 ve Çizelge 4).

\section{Bulgular ve Tartıșma}

Araștırmanın yürütüldüğü yıllara ait çiçeklenme bașlangıcı (\%10) ve fizyolojik olum gün sayısı, dal sayısı, bitki boyu, bitkide bakla, baklada tane ve ilk bakla yüksekliği gibi parametreler oldukça farklılık göstermektedir. Yıl faktörü bu çalıșmada incelenen tüm parametrelerde \%1'de çok önemli bulunmuștur. Çeşit/popülasyon faktörünün verim unsurlarının tümüne olan etkisi $\% 1$ düzeyinde olup yıl $x$ ç/p interaksiyonu da ilk bakla yüksekliğinde $\% 5$ diğer parametrelerde ise \%1'de önemli bulunmuştur (Çizelge 4).

Çiçeklenme bașlangıcı ve fizyolojik olum gün sayısı: Çiçeklenme ve olgunlașma bașlangıcına kadar geçen süre ortalamaları sırası ile 56 ve 119 gün civarında olmuştur. En erkenci çeşitler Seher ve Lara (17 gün) olduğundan, yine en erken çiçek veren çeşitlerde Seher (49 gün) ve Lara (53 gün) olmuștur. Çiçeklenmenin \%10 tamamlandığı dönem esas alınmıș (Akçin, 1982) ve 2012 yllında ortalama 52.2 gün 2013 yllında ise 59.9 gün de çiçeklenme tamamlanmıștır. Olgunlașma bașlangıcına kadar olan süre 2012 yılında 117.1 gün 2013 yllında ise 121.8 gündür. Her iki yılda en geç olgunlașan popülasyon Geyve (a1) 130 günde hasat edilmiș, en erken olgunlașan genotip ise Seher çeşidi (97 gün) olmuștur. Bakla ıslahı çalıșmalarında bakla vejetasyon süresinin 100-180 gün arasında değiștiği belirtilmiştir (Firschbeck ve ark., 1975).

Çizelge 4. Bazı bakla çeșit ve popülasyonlarının tarımsal özelliklerine ilișkin değerler Table 4. Some agricultural characteristics values of some faba bean variety/populations

\begin{tabular}{|c|c|c|c|c|c|c|c|c|c|c|}
\hline \multirow{2}{*}{$\begin{array}{l}\mathrm{G} \\
\mathrm{a} 1\end{array}$} & \multicolumn{2}{|c|}{$\begin{array}{l}\text { Çiçeklenme } \\
\text { gün sayısı }\end{array}$} & \multicolumn{2}{|c|}{$\begin{array}{l}\text { Fizyolojik olum } \\
\text { gün sayısı }\end{array}$} & \multicolumn{2}{|c|}{$\begin{array}{l}\text { Bitki boyu } \\
\text { (cm) }\end{array}$} & \multicolumn{2}{|c|}{$\begin{array}{l}\text { Yan dal sayısı } \\
\text { (adet) }\end{array}$} & \multicolumn{2}{|c|}{$\begin{array}{l}\text { İlk bakla } \\
\text { yüksekliği (cm) }\end{array}$} \\
\hline & 62.2 & $A$ & 127.5 & $A$ & 53.0 & $\mathrm{~J}$ & 5.9 & A & 26.8 & $\mathrm{H}$ \\
\hline a2 & 54.8 & EF & 116.7 & $\mathrm{~F}$ & 60.3 & D-G & 4.0 & $\mathrm{D}-\mathrm{H}$ & 22.4 & IJ \\
\hline a3 & 59.0 & $B$ & 119.3 & $\mathrm{C}-\mathrm{F}$ & 62.6 & $\mathrm{C}-\mathrm{F}$ & 4.2 & $D-G$ & 33.8 & $A B$ \\
\hline a4 & 53.8 & $F G$ & 120.3 & $\mathrm{C}-\mathrm{F}$ & 66.9 & $A B$ & 5.4 & $A$ & 26.6 & $\mathrm{H}$ \\
\hline a5 & 55.8 & $\mathrm{DE}$ & 119.0 & $\mathrm{D}-\mathrm{F}$ & 56.9 & G-J & 4.4 & $B-D$ & 16.9 & $M$ \\
\hline an1 & 58.2 & $\mathrm{BC}$ & 123.7 & $A B$ & 54.9 & IJ & 4.8 & $\mathrm{BC}$ & 18.7 & $\mathrm{~L}$ \\
\hline an2 & 56.8 & CD & 123.7 & $A-C$ & 54.9 & IJ & 3.8 & $\mathrm{GH}$ & 30.6 & $\mathrm{DE}$ \\
\hline b1 & 57.8 & $\mathrm{BC}$ & 120.7 & B-E & 58.6 & F-I & 3.6 & $\mathrm{H}$ & 24.0 & I \\
\hline b2 & 58.5 & $B$ & 117.0 & $\mathrm{EF}$ & 55.0 & IJ & 4.3 & C-E & 26.6 & $\mathrm{H}$ \\
\hline ç1 & 55.3 & $D-F$ & 117.3 & $\mathrm{EF}$ & 57.9 & G-I & 4.1 & $\mathrm{D}-\mathrm{H}$ & 22.1 & $J$ \\
\hline ç2 & 55.5 & $\mathrm{DE}$ & 118.7 & $\mathrm{D}-\mathrm{F}$ & 59.6 & $\mathrm{E}-\mathrm{G}$ & 3.6 & $\mathrm{H}$ & 29.2 & EF \\
\hline m1 & 55.7 & $\mathrm{DE}$ & 120.3 & $\mathrm{C}-\mathrm{F}$ & 55.1 & IJ & 4.0 & $\mathrm{D}-\mathrm{H}$ & 27.4 & $\mathrm{GH}$ \\
\hline $\mathrm{m} 2$ & 58.2 & $\mathrm{BC}$ & 118.8 & $\mathrm{D}-\mathrm{F}$ & 59.7 & $E-G$ & 4.9 & B & 20.4 & $\mathrm{~K}$ \\
\hline s1 & 55.7 & $\mathrm{DE}$ & 122.2 & $B-D$ & 59.0 & E-I & 4.3 & $\mathrm{C}-\mathrm{F}$ & 18.8 & $\mathrm{KL}$ \\
\hline $\mathrm{t} 1$ & 55.5 & $\mathrm{DE}$ & 122.7 & $A-C$ & 55.1 & IJ & 4.3 & $\mathrm{C}-\mathrm{F}$ & 32.5 & $\mathrm{BC}$ \\
\hline e1 & 55.3 & $D-F$ & 117.7 & $\mathrm{D}-\mathrm{F}$ & 64.4 & $A-D$ & 3.1 & I & 29.3 & EF \\
\hline e2 & 55.2 & $\mathrm{EF}$ & 119.0 & $\mathrm{D}-\mathrm{F}$ & 66.7 & $A-C$ & 3.8 & $\mathrm{~F}-\mathrm{H}$ & 32.2 & CD \\
\hline e3 & 55.3 & $D-F$ & 119.0 & $D-F$ & 67.4 & A & 3.1 & I & 35.1 & A \\
\hline e4 & 56.2 & $\mathrm{DE}$ & 121.3 & $B-D$ & 63.0 & $B-E$ & 3.1 & I & 23.3 & IJ \\
\hline $\mathrm{L}$ & 53.0 & $\mathrm{G}$ & 125.0 & $A B$ & 59.4 & $\mathrm{E}-\mathrm{H}$ & 3.9 & $\mathrm{E}-\mathrm{H}$ & 28.6 & $\mathrm{FG}$ \\
\hline $\mathrm{S}$ & 48.8 & $\mathrm{H}$ & 98.5 & $\mathrm{~F}$ & 55.3 & H-J & 3.9 & $\mathrm{E}-\mathrm{H}$ & 29.5 & $\mathrm{EF}$ \\
\hline LSD & & 1.15 & & 2.84 & & 2.92 & & 0.33 & & 1.17 \\
\hline $\mathrm{CV}$ & & $2.5 \%$ & & $3 \%$ & & $6 \%$ & & $10 \%$ & & $6 \%$ \\
\hline YIL & & ** & & $\star \star$ & & $\star \star$ & & $\star \star$ & & $\star \star$ \\
\hline GENC & TiP & $\star \star$ & & $\star \star$ & & $\star \star$ & & $\star \star$ & & $\star \star$ \\
\hline YIL X & & $\star *$ & & $\star \star$ & & $\star *$ & & $\star *$ & & * \\
\hline
\end{tabular}

Aynı sütun içerisinde aynı harf ile gruplandırılan ortalamalar LSD \%5'e göre farklı değildir.

** $\mathrm{P}<0,01$ intimalle önemli * $\mathrm{p}<0,05$ intimalle önemli

The averages grouped with letters in the same column are not different according to LSD $5 \%$.

${ }^{* *} P<0.01$ possible significant ${ }^{*} p<0.05$ possible significant 
Bitki boyu: 2012 yilında ortalama $62.1 \mathrm{~cm}$ olan bitki boyu; e2 (Eresen-87) çeşidinde 75.8 $\mathrm{cm}$ olarak en yüksek, Seher çeșidinde ise 48.6 $\mathrm{cm}$ ile en düșük değer olarak ölçülmüștür. 2013 yllında ise bitki boyu ortalama $56.5 \mathrm{~cm}$ olmuș, en yüksek ve en düșük değerler sırası ile e3 (Kıtık $(72.4 \mathrm{~cm})$ ) çeşidi ve m1 (47.8 $\mathrm{cm})$ popülasyonundan alınmıș olup benzer çalıșmalarda da aynı sonuçlar elde edilmiștir (Adak ve ark., 1999; Bozoğlu, 1989). Çalıșmada genotip ve yıllar arasında \%1 önem seviyesinde farklılıklar belirlenmiștir (Çizelge 4). Heinzmann (1981); Gençkan (1983); Sepetoğlu (1992); Ceyhan (2007) tarafından kıș dönemindeki ılık havanın baklada bitki boyunu artırdığı ifade edilmiștir.

Yan dal sayısı: Baklagillerde gövde boğum ve boğum aralıklarından olușmaktadır ve her bir boğum, yaprak, çiçek salkımı, meyve gibi yeni bir bitki aksamının çıktığı yerdir. Bitki çıkıș yapıp yapraklarını olușturduktan sonra vejetatif gelișmenin hızlandığı devrede dallanma gerçekleșmektedir. Baklada dallanma, toprak seviyesinden olmaktadır. Çalıșmada ortalama dal sayısı 2012 yılında 4.52013 yilında ise 3.8 adet olmuștur. Dal sayısının en yüksek olduğu popülasyonlar birinci yıl $\mathrm{m}^{2}$ (6.1 adet) ikinci yıl ise a1 (6 adet) olmuștur. Nitekim çalıșmada genotip, yıl ve yıl $x$ ç/p interaksiyonunda \%1 önem seviyesinde farklılıklar ortaya çıkmıștır. Dolayısı ile Pasinler'de yapılan ilkbahar ekimleri ile ılıman hava șartlarından nispeten yararlanılmıș ayrıca her iki yılda sıcaklık ve yağıș arasındaki așırı dengesizlikler bitkinin dallanmasında etkili olmuș olabilir (Çizelge 3 ve Çizelge 4). Dallanma dolayısı ile vejetatif aksam olușturmanın popülasyonlarda daha fazla olduğu ayrıca ekim sonrası yağıșın dallanmada etkili olduğu ve bunun interaksiyonun önemli olmasına neden olduğu da belirtilebilir. Elde edilen veriler yapılan benzer çalıșmalarla da paralellik göstermektedir (Bozoğlu, 1989; Artık ve Pekșen, 2005; Pekșen ve Gülümser, 2007).

İlk bakla yüksekliği: Makinalı hasada uygunluk bakımından ilk bakla yüksekliği önemli bir unsur olup, uzun boylu ve baklaları toprağa göre daha yüksekte olușan çeșitler makine ile hasat edilebilmektedirler. İki yıllık ortalamaya göre ortalama $26.4 \mathrm{~cm}$ olan ilk bakla yüksekliği ortalama olarak 2012 yılında 25.8 cm 2013 yilında ise $27 \mathrm{~cm}$ olarak belirlenmiștir.
En düșük ilk bakla yüksekliği değeri birinci yıl S (Seher) çeșidinde $17 \mathrm{~cm}$ ikinci yıl ise a5 (Erenler) popülasyonunda $16.2 \mathrm{~cm}$ olarak kaydedilmiștir. İlk bakla yüksekliği genotip ve çevresel faktörlere bağlıdır (Fehr, 1987; Önder ve Șentürk, 1996). Benzer șekilde, çalıșmada da yıl ve genotipin ilk bakla yüksekliği üzerine önemli etkide bulunduğu görülmüștür (Çizelge 4).

Bitkide bakla sayısı: 2012 yllında bitki bașına bakla sayısı 11.0-20.4 adet aralığında değișmiș olup ortalama 16.1 adet 2013 yllında ise 9.9-19.3 adet aralığında değișen bakla sayısı ortalama 13.7 adet olmuștur. Çalışmada ortalama olarak 14.9 adet olan bitkide bakla sayısı yapılan bazı çalıșmalarla benzerlik göstermektedir. Benzerlik gösteren bu çalıșmalarda çeșitlere bağlı olarak Şehirali (1988) ve Sepetoğlu (1992) bitkide bakla sayısını 1-9 adet, Bozoğlu (1989) bakla çeșit/ hatlarında bitkide bakla sayısını 16-22 adet, Bozoğlu ve ark. (2002) 8.9-9.4, Lara'da 9.6 adet olarak, Li-juan (1993) ise bitkide bakla sayısını uzun baklalı ve iri tohumlu bakla hatlarında 6.6-17.1 adet, Ece ve ark. (2004) da2.9-5.6 adet arasında tespit etmișlerdir. Çalışmada çeşit ve popülasyonların bitkide bakla sayısı farklılık göstermiș ve bu farklılık genotip, yıl, yıl $\mathrm{x} c ̧ / p$ interaksiyonunun \%1'de önemli olmasına neden olmuștur (Çizelge 5). Bitki bașına bakla sayısı çevre șartlarından etkilenmekte (Balkaya, 1999; Bozoğlu ve Gülümser, 2000; Ülker, 2008) ve özellikle iklimsel faktörlere bağlı olarak yıllar arasında bakla sayısı bakımından önemli farklıııklar gösterebilmektedir (Anlarsal ve ark., 2000; Elkoca ve Kantar, 2004; Pekșen, 2005).

Baklada tane sayısı: 2012 yılında baklada tane sayısı 2.8-4.5 aralığında değișirken ortalama 3.7 adet olmuș en yüksek değer a1 (Geyve) popülasyonundan alınmıștır. 2013 yılında ise 1.6-4.0 aralığında değișen bakla sayısı ortalama 2.8 adet olmuș ve ne yüksek baklada dane sayısı e2 (Eresen-87) çeșidinden alınmıștır. Nitekim çalıșmada genotip ve yıllar arasında \%1 önem seviyesinde farklılıklar ortaya çıkmıștır (Çizelge 5). Araștırmada olduğu gibi yapılan diğer pek çok çalıșmada da önemli bir genotipik karakter olan baklada tane sayısı bakımından genotipler arasında önemli farklılıkların bulunduğu bildirilmektedir. 
Çizelge 5. Bazı bakla çeşit ve popülasyonlarının tohum verimi ve bakla özelliklerine ilișkin değerler Table 5. Seed yield and some characteristics values of some faba bean varieties/populations

\begin{tabular}{|c|c|c|c|c|c|c|}
\hline \multirow{2}{*}{$\begin{array}{l}\text { Genotip } \\
\text { a1 }\end{array}$} & \multicolumn{2}{|c|}{ Bitkide bakla (adet) } & \multicolumn{2}{|c|}{ Baklada dane (adet) } & \multicolumn{2}{|c|}{ Tohum verimi $(\mathrm{kg} / \mathrm{da})$} \\
\hline & 15.5 & $A-C$ & 3.7 & $A$ & 98.2 & $\mathrm{H}$ \\
\hline a2 & 14.4 & $B-D$ & 3.0 & $C-G$ & 100.6 & $\mathrm{H}$ \\
\hline a3 & 15.4 & $A-C$ & 3.1 & $C-G$ & 128.2 & $\mathrm{G}$ \\
\hline a4 & 14.4 & $B-D$ & 2.9 & $D-G$ & 155.3 & $\mathrm{~F}$ \\
\hline a5 & 15.4 & $A-C$ & 2.8 & $\mathrm{FG}$ & 162.5 & $\mathrm{~F}$ \\
\hline an1 & 15.8 & $A-C$ & 3.1 & $B-G$ & 161.0 & $\mathrm{~F}$ \\
\hline an2 & 17.2 & $A$ & 3.3 & B-F & 152.8 & $\mathrm{~F}$ \\
\hline b1 & 16.0 & $A B$ & 3.3 & $A-E$ & 152.9 & $\mathrm{~F}$ \\
\hline b2 & 15.3 & $A-D$ & 3.4 & $A-D$ & 122.3 & $\mathrm{G}$ \\
\hline ç1 & 14.5 & $B-D$ & 3.4 & $A-D$ & 154.6 & $\mathrm{~F}$ \\
\hline ç2 & 15.8 & $A-C$ & 3.5 & $A-C$ & 122.6 & $G$ \\
\hline $\mathrm{m} 1$ & 17.1 & $A$ & 3.3 & B-F & 105.7 & $\mathrm{H}$ \\
\hline $\mathrm{m} 2$ & 14.5 & B-D & 3.3 & B-F & 163.1 & $\mathrm{EF}$ \\
\hline s1 & 11.3 & $E$ & 3.1 & $C-G$ & 223.6 & $\mathrm{C}$ \\
\hline $\mathrm{t} 1$ & 13.6 & $C D$ & 3.4 & $A-D$ & 232.1 & $\mathrm{BC}$ \\
\hline e1 & 14.4 & B-D & 3.4 & $A-D$ & 224.6 & C \\
\hline e2 & 13.9 & B-D & 3.3 & $A-E$ & 250.8 & $A$ \\
\hline e3 & 13.1 & $\mathrm{DE}$ & 3.2 & B-F & 174.0 & $E$ \\
\hline e4 & 14.3 & $B-D$ & 3.2 & $B-G$ & 237.0 & $B$ \\
\hline L & 14.3 & $B-D$ & 2.8 & $E-G$ & 161.3 & $\mathrm{~F}$ \\
\hline$S$ & 15.7 & $A-C$ & 3.6 & $A B$ & 195.9 & $\mathrm{D}$ \\
\hline LSD & & 1.592 & & 0.298 & & 7.98 \\
\hline CV & & $13 \%$ & & $11 \%$ & & $6 \%$ \\
\hline YIL & & $\star *$ & & $\star *$ & & $\star \star$ \\
\hline GENOTIP & & $\star \star$ & & $\star *$ & & $\star *$ \\
\hline YIL X Ç/P & & $* *$ & & $\star *$ & & ** \\
\hline
\end{tabular}

Aynı sütun içerisinde aynı harf ile gruplandırılan ortalamalar LSD \%5'e göre farklı değildir.

${ }^{* *} \mathrm{P}<0,01$ intimalle önemli ${ }^{*} \mathrm{p}<0,05$ intimalle önemli

The averages grouped with letters in the same column are not different according to LSD $5 \%$.

${ }^{* *} P<0.01$ possible, * $p<0.05$ possible,

Baklalar kıșlık ekim șartlarında daha iyi kök gelișimi göstermiș olmaları nedeni ile yaz kuraklarından yazlık ekimdekine oranla daha az etkilenmektedirler. Dolayısı ile Pasinler'de yapılan ilkbahar ekimleri ile ılıman hava șartlarından nispeten yararlanılmıș ayrıca her iki yılda sıcaklık ve yağıș arasındaki așırı dengesizlikler bitkinin bakla ve tane olușturmasına olumsuz etkide bulunmuștur (Çizelge 3 ve Çizelge 5).

Tohum verimi: 2012 yilında ortalama 204.2 $\mathrm{kg} \mathrm{da}^{-1}$ olmuș ve 2012 yilında en yüksek değer e2 (Eresen-87) çeșidinde (402 kg da$\left.{ }^{1}\right)$ en düșük değer ise $96.6 \mathrm{kgda}^{-1}$ olarak a1 (Geyve) populasyonundan alınmıștır. 2013 yilında ise ortalama $127.2 \mathrm{~kg} \mathrm{da}^{-1}$ olan tohum veriminde en yüksek verim $T$ (Tokat (212.1 $\mathrm{kg} \mathrm{da))} \mathrm{en} \mathrm{düșük} \mathrm{verim} \mathrm{ise} \mathrm{an1} \mathrm{(Antalya)}$ popülasyonundan alınmıștır (Çizelge 5).Tohum verimi yıllara ve çeșide bağlı olarak değișim gösterebilmektedir (Yaman, 1996; Matthews ve Marcellos, 2003). Çalışmada 2012 yılında yağışların düzenli olușu nemin elverișli olması ayrıca toprak șartlarının 2013'e nazaran daha uygun olması yüksek tane verimine etki etmiș olabilir. Nitekim çalıșmada genotip ve yıllar arasında \%1 önem seviyesinde farklılıklar belirlenmiștir. Farklı dane baklagillerde farklı genotip x çevre interaksiyonları vardır. Baklada tohum veriminin kalıtsal olması ya da aynı 
sonuçların tekrarlanması çok düșük olmasına rağmen tespit edilen değișimler genetik etkilere bağlı olabilir çünkü genotiplerin verim cevapları farklı olabilmektedir. Ortalama olarak dekara $500 \mathrm{~kg}$ civarında tohum verimi alınan baklada çiçeklenmenin çok olmasına karșlık paralelinde dökülmenin de fazla olduğu ayrıca çevresel faktörlerin de çok etkin olduğu araștırmacılar tarafından belirtilmektedir (Munteanu, 1979; Gehriger ve Keller, 1980; Richiardi, 1981; Salih, 1983; Özdemir, 2002).

Verim ve verim unsurları arası korelasyon: Islahta amaca uygun çeșitlerin geliștirilmesinde bitkilerin verimi ile verim unsurları arasındaki ilișkiden yararlanılması seçim yapılmasında kolaylık sağlamaktadır. Basit korelasyon analizi ile korelasyon katsayıları hangi özelliklerin kullanılacağını belirlemek açısından oldukça önemli olmakla birlikte masrafları azaltmakta ve aynı zamanda zaman ve ișgücü tasarrufu da sağlamaktadır (Anlarsal ve Gülcan, 1989; Sayar ve Bașbağ, 2018).

Çalışmada tohum verimi ile çiçeklenme ve fizyolojik olum gün sayısı arasında negatif (\%1) bitki boyu ve bitkide tane sayısı ile pozitif (\%1) çok önemli bir ilișki görülmektedir (Çizelge 6). Yapılan birçok ıslah çalıșmasında verim ve verimle bağlantılı unsurlar arasındaki korelasyonlarda baklada yüksek verim için bitkide bakla sayısı, tohum ağırlığı, bitki boyu ve bitkide dal sayısının önemli faktörler olduğu (Mohamed, 1985), tohum veriminin bitkide dal, bitkide bakla, salkımda bakla, bitkide tohum sayısı, bitki boyu,1000 tane ağırlığı ve bakla boyu ile kesin ilișkili olduğu (Ricciardi,1981), bitkide dal, tohum ve bakla sayısının tohum verimi ile olumlu ve önemli ilișkileri olduğu (Sindhu ve ark.,1985), tane verimi ile bitki boyu, ana dal sayısı, bakla sayısı ve tane sayısı arasında pozitif ve önemli ilișkiler bulunduğu (Kıtıkı ve Açıkgöz,1994) belirtilmiștir. Bazıları da tane verimi ile hasat indeksi, bakla uzunluğu, baklada tane sayısı ve biyolojik verim arasında olumlu ve çok önemli; çiçeklenme süresi, hasat olgunluk suresi, ilk bakla bağlama suresi ve bitki bașına dal sayısı ile olumsuz ilișkiler gösterdiğini (Abo-Elwafa ve Bakheit, 1999; Reddy ve ark., 2002; Pekșen, 2007) bildirmișlerdir.

\section{Sonuç}

Araștırmada Erzurum șartlarında baklanın dekara 98.2-250.8 kg aralığında tohum verebileceği ve tohum üretimi için e2 (Eresen-87) çeşidinin ön plana çıktığı görülmüştür. Korelasyonlarda tohum verimi ile bitki boyu ve baklada tane sayısı arasında çok önemli (\%1) ve yüz tane ağırığı arasında ise önemli (\%5) pozitif ilișki belirlenmiștir. $\mathrm{Bu}$ nedenle yüksek tohum veriminde bitki

Çizelge 6. Tohum verimi ve verim unsurları arası korelasyon katsayıları

Table 6. Correlation coefficients between seed yield and yield components

\begin{tabular}{|c|c|c|c|c|c|c|c|c|c|}
\hline & ÇGS & ÇiGS & FOGS & İBY & BB & DS & BBS & BTS & YTA \\
\hline ÇGS & ------ & & & & & & & & \\
\hline ÇIGGS & 0.143 & ------ & & & & & & & \\
\hline FOGS & 0.153 & $0.535^{\star \star}$ & ------ & & & & & & \\
\hline IBBY & -0.005 & 0.136 & $0,324^{\star \star}$ & ------ & & & & & \\
\hline BB & 0.121 & $-0.432^{\star *}$ & $-0.200^{\star *}$ & 0.180 & ------ & & & & \\
\hline DS & $0.246^{\star *}$ & -0.190 & -0.013 & -0.210 & 0.127 & ------ & & & \\
\hline BBS & -0.061 & $-0.289^{\star *}$ & -0.154 & $-0.237^{\star \star}$ & 0.074 & 0.160 & ------ & & \\
\hline BTS & -0.079 & $-0.437^{\star *}$ & -0.194 & 0.016 & 0.162 & $0.251^{* *}$ & $0.360^{\star *}$ & ------ & \\
\hline YTA & -0.038 & -0.141 & -0.042 & 0.158 & $0.490^{* *}$ & $-0.280^{* *}$ & -0.181 & -0.078 & ------ \\
\hline TV & -0.176 & $-0.548^{\star \star}$ & $-0.292^{\star \star}$ & 0.031 & $0.402^{\star \star}$ & -0.004 & 0.040 & $0.282^{\star \star}$ & $0.177^{\star}$ \\
\hline
\end{tabular}

** $P<0,01$ intimalle çok önemli * $p<0,05$ intimalle önemli

ÇGS: Çıkıș gün sayısı, ÇiGS: \%10 Çiçeklenme bașlangıcı gün sayısı, FOGS: Fizyolojik olum gün sayısı, İBY: İlk bakla yüksekliği BB: Bitki boyu, DS: Dal sayısı, BBS: Bitkide bakla sayısı, BTS: Baklada tane sayısı, YTA: Yüz tane ağırlığ, TV: Tohum verimi

$P<0.01$ possible significant, ${ }^{*} p<0.05$ possible significant

ÇGS: Number of days of germination, ÇGS: $10 \%$ Number of flowering days, FOGS: Number of days of physiological mature, IBY: First pod height BB: Plant height, DS: Number of branches, BBS: Number of pods per plant, BTS: Number of pods per pod, YTA : One

hundred grain weight, TV: Seed yield 
boyu, baklada tane sayısı ile yüz tane ağırlığı kriterlerinin Erzurum ve benzer ekolojilerde yapılacak ıslah çalıșmalarında seleksiyon kriterleri olarak kullanılabileceği ifade edilebilir.

\section{Teșekkür}

Araștırma, Tarımsal Araștırmalar ve Politikalar Genel Müdürlüğü'nün TAGEM/TBAD/12/ A03/P01/004 nolu projesi kapsamında desteklenmiștir.

\section{Kaynaklar}

Açıkgöz, E., 2001. Yem Bitkileri. Yenilenmiș 3. Baskı. Uludağ Üniversitesi, Ziraat Fakültesi Tarla Bitkileri Bölümü. Uludağ Üniversitesi Vakfı, Bursa. Yayın No: 182, s: 584.

Abo-Elwafa, A.A.,\& Bakheit, B.R., 1999. Performance, correlations and path-coefficient analysis in faba bean. Assiut J. of Agric. Sci., 30: 77-92.

Adak, M.S., Ulukan, H., \& Güler, M., 1999. Determination of Some Agronomical Traits in Turkish Faba Bean (Vicia faba L.) Lines, FABIS, 42:29-31 ICARDA.

Akçin, A., 1982. Hayvan Baklası Kültürünün Teknik Esasları. Atatürk Üniversitesi Yayınları: 585, Ziraat Fakültesi Yayınları: 266, Erzurum.

Akçin, A., 1988. Yemeklik Tane Baklagiller. Selçuk Üniversitesi Yayınları: 43, Ziraat Fakültesi Yayınları: 8,Konya.

Anlarsal A., Gülcan H.1989. "Çukurova Koşullarında Fiğ (V.Sativa L.) Çeșitlerinde Ot Verimi Ve Bazı Önemli Verim Unsurları Üzerinde Path Analizi, Doğa Bilim Dergisi”, Türk Tarım ve Ormancılık Dergisi, cilt.13, ss.487-494.

Anlarsal, A.E., Yücel, C., \& Özveren, D., 2000. Çukurova koşullarında bazı fasulye (Phaseolus vulgaris L.) çeșitlerinde tane verimi ve verimle ilgili özellikler ile bu özellikler arası ilișkilerin saptanması. Turkish Journal of Agriculture and Forestry, 24: 19-29.

Artık, C.\& Pekșen, E.,2005. Gama ıșınlamasının M1 generasyonunda bakla (Vicia faba L.)'nın bazı bitkisel özellikleri üzerine etkileri. O.M.Ü. Ziraat Fakültesi Dergisi, 20 (3): 44-53.

Balkaya, A., 1999. Karadeniz Bölgesindeki Taze Fasulye (Phaseolus vulgaris L.) Gen Kaynaklarının Toplanması, Fenolojik ve Morfolojik Özelliklerinin Belirlenmesi ve Taze Tüketime Uygun Tiplerin Teksel Seleksiyon Yöntemi ile Seçimi Üzerinde Araștırmalar. Ondokuz Mayıs Üniversitesi Fen Bilimleri Enstitüsü Bahçe Bitkileri Ana Bilim Dalı (Doktora Tezi), Samsun.

Bozoğlu, H., 1989. Samsun Ekolojik Şartlarında Farklı Zamanlarda Ekilen Bakla Çeșitlerinin Gelișme Durumları ve Verimleri Üzerinde Bir Araștırma. O.M.Ü. Fen Bilimleri Enstitüsü Yüksek Lisans Tezi (Basılmamıș), 83, Samsun.
Bozoğlu, H.,\& Gülümser, A., 2000. Kuru fasulyede (Phaseolus vulgaris L.) bazı tarımsal özelliklerin genotip çevre interaksiyonları ve stabilitelerinin belirlenmesi üzerine bir araștırma. Turkish Journal of Agriculture and Forestry, 24: 211-220.

Bozoğlu, H., A. Pekșen, E. Pekșen, A.,\& Gülümser, 2002. Determination of gren pod yield and some pod characteristics of faba bean (Vicia faba L.) cultivar/linesgrown in different row spacings. Acta Horticulturae,579: 347-350.

Ceyhan, E. 2007. Yemeklik Tane Baklagiller. Selçuk Üniversitesi Ziraat Fakültesi Tarla Bitkileri Bölümü ders notları, 42070 Selçuk / Konya.

Ece, A.,Düzdemir, O., Akdağ, C.,\& Uysal, F.,2004. Kıșlık ve yazlık ekilen bakla'da (Vicia faba L.) bazı bitkisel özelliklerin belirlenmesi. V. Sebze Tarımı Sempozyumu (21-24 Eylül 2004), Çanakkale.

Elkoca, E.,\& Kantar, F., 2004. Erzurum Ekolojik Koșullarına Uygun Erkenci ve Yüksek Verimli Kuru Fasulye (Phaseolus vulgaris L.) Genotiplerinin Belirlenmesi. Atatürk Üniversitesi Ziraat Fakültesi Dergisi 35 (3-4): 137-142.

Fehr, W.R. 1987. Genotyp x enviroment interaction. Principles of cultivar development, Vol: I. Theoryand Tecnique. Macmillan Publishing Company, New York, pp: 247-260.

Firschbeck, G.,Heyland, K., \& Knauer, N.,1975. Pflanzenbau, UlmerVerlag, s:166-167.

Gehriger, W.,\& Keller, E. R., 1980. Influence of topping of faba beans (Vicia faba L.) on their growth and on the supply of the flower swith 14 C. FABIS-Newsletter. Faba-Bean-InformationService,-ICARDA, (2): 33.

Gençkan, M.S. 1983. Yem Bitkileri Tarımı, Ege Üniversitesi Ziraat Fakültesi Yayınları No:467, İzmir, $519 \mathrm{~s}$.

Geren, H., \& Alan, Ö., 2005. Ödemiș Koșullarında yetiștirilen bazı bakla (Vicia faba var. Major) çeșitlerinin hası verimi ve diğer bazı özellikleri üzerine bir araștırma. Ege Üniv. Zir. Fak. Derg. 2005, 42 (1): 59-66.

Heinzmann, F., 1981. Assimilation von Luftsticks toff durchver schiedene Leguminose narten und desen Verwertung durch Gefreiden achfrüchte, Diss, Hohenheim, page:132.

Karadavut, U., Kayıș, S. A., Keskin, İ., 2011. Bazı Bakla (Vicia faba L.) Genotiplerinde Tane Verimi ve Verime Etki Eden Özellikler Arasındaki İlișkilerin Belirlenmesi. Anadolu Tarım Bilimleri Derg.,2011, 26 (1): 30-35.

Kıtıkı, A.\& Açıkgöz, N.,1994. Baklada verime katkısı olan özelliklerin katkı paylarının belirlenmesi. Tarla Bitkileri Kongresi, 25-29 Nisan 1994. Cilt II: 112-115. Bornova İzmir.

Kün, E, Çiftçi, G.Y, Birsin, M., Ülger, A.C., Karahan, S., Zencirci, N., Atak, M., 2005. Tahıl ve Yemeklik Dane Baklagil Üretimi: Yemeklik Dane Baklagiller. Türkiye Ziraat Mühendisliği V. Teknik Kongresi, 3-7 Ocak 2005. Ankara, S: 396-407.

Li-juan, L., 1993. Research on breeding and germplasm resource of autumn-sown faba bean. FABIS Newsletter, 32: 11-14. 
Matthews, P. \& Marcellos,T.H., 2003, Faba Bean, Agfact P4.2.7, Division Plant Industries. http:// www.raa.nsw.gov.au/reader/faba-bean-agfact

Mohamed, M.B. 1985. Effect of Sowing Date, Ridge Direction, Plant Orientation and Population on Faba Bean Grain Yield. Fabis Newsletter August 1985 No:12,11-13. Icarda.

Munteanu, N., 1979. Research on Some Field Bean Populatıons From Moldavia, Field Crops Abstracts Vol.46, No:10. Özdemir, S., 2002. Yemeklik Baklagiller, Hasad Yayıncılık, Adana, 142s.

Önder, M.,\& Şentürk, D., 1996. Ekim zamanlarının bodur kuru fasulye çeşitlerinde dane ve protein verimi ile verim unsurlarına etkisi. Selçuk Üniversitesi Ziraat Fakültesi Dergisi, 10 (3): 7-18.

Özdemir, S., 2002. Yemeklik Baklagiller. Hasat Yayıncılık Ltd. Ști., ISPN. 978-975-8377-01-8, S.144.

Pekșen, E., 2005. Samsun koșullarında bazı fasulye (Phaseolus vulgaris L.) genotiplerinin tane verimi ve verimle ilgili özellikler bakımından karșılaștırılması. OMÜ Ziraat Fakültesi Dergisi, 20 (3): 88-95.

Pekșen, E., 2007. Bakla (Vicia faba L.)'da Özellikler Arasındaki İlișkiler ve Tane Verimi bakımından Seleksiyon Kriterlerinin Belirlenmesi. OMU Zir. Fak.Dergisi., 2007,22 (1): 73-78.

Pekșen, A., Pekșen, E., \& Artık, C. 2006. Bazı Bakla (Vicia Faba L.) Popülasyonlarının Bitkisel Özellikleri ve Taze Bakla Verimlerinin Belirlenmesi. OMU Zir.Fak.Dergisi., 2006,21(2): 225-230.

Pekșen, E. \& Gülümser, A., 2007. Comparison of Faba Bean (Vicia faba L.) Genotypes Sown in Autumn and Spring for Some Plant Characters and Seed Yield. Anadolu Journal of AgriculturalSciences (Turkey).
Reddy, S.R.R.,Gupta, S.N., \& Verma, P.K., 2002. Genetic variability, association and path analysis in Vicia faba L. Under high fertility conditions. Forage Research, 28: 169-173.

Ricciardi, 1981. Variability of Biological and Agronomic Characters in Accessiens of Vicia faba L. Annalidelle Facoltadi Agronia Universitadi Beni 1981-1982, Recd 1985. No:32, 119-114, Italy.

Salih, F.A., 1983. Influence of Sowing Date, Seed Rate and Seed Size on Yield and Yield Components of Faba Beans. Fabis Newsletter 1983 No:7, 32.

Sayar, M. S.\& Bașbağ, M., 2018. Determınıng relatıonshıps between seed yıeld and ımportant agricultural traits with correlation and path analysıs in some narbonvetchlınes. International engineering and natural sciences conference (IENSC 2018), Nov. 2018, 197.-203.

Sepetoğlu, H. 1992. Yemeklik Dane Baklagiller, Ege Üniversitesi Ziraat Fakültesi Yayınları Ders Notları:24, İzmir, $262 \mathrm{s.}$

Sındhu, J.S., Sıngh, O.P.,\& Sıngh, K.P. 1985. Compenent Analysis of the Factors Determining GrainYield in Faba Bean. Fabis Newsletter December 1985. No:13. Icarda.

Şehirali, S.,1988. Yemeklik Dane Baklagiller, Ankara Üniversitesi Ziraat Fakültesi Yayınları:1089, Ders Kitabı:314, Ankara, 435s.

TÜiK 2019. http://www.tüik.gov.tr

Ülker, M., 2008. Orta Anadolu Ekolojik Șartlarında Yetiștirilen Fasulye (Phaseolus vulgaris L.) Genotiplerinin Bazı Tarımsal ve Kalite Özelliklerinin Belirlenmesi. Selçuk Üniversitesi Fen Bilimleri Enstitüsü (Yüksek Lisans Tezi), Konya.

Yaman, M., 1996, Bakla Tarımı ve Eresen-87 Çeșidi, Ege Tarımsal Araș.Enst., Çiftçi Broşürü No:64, Menemen-İzmir. 